\title{
Magnetická rezonance u dospělých pacientů s rekoarktaci aorty
}

Incidence koarktace aorty $(\mathrm{CoA})$ se nejčastěji udává 40-60 postižených na 100000 živě narozených dětí. Většina těchto pacientů byla diagnostikována a operována v dětství, rekoarktace aorty (reCoA) se vyskytne přibližně u $2,2-10 \% \mathrm{z}$ nich.

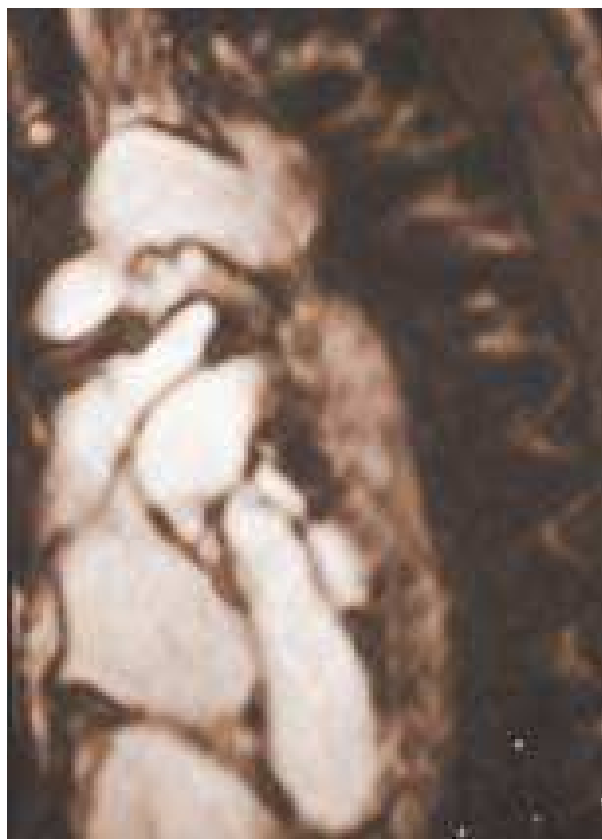

Obr. 1 Vyšetření bez aplikace Gadolinia v B-FFE sekvenci (balancované gradientní sekvenci) hemodynamicky závažná rekoarktace

V současné době je za metodu volby v terapii reCoA považována perkutánní balonková angioplastika, která by měla být vzhledem k možným závažným komplikacím (disekce, aneurysma, ruptura aorty) prováděna $\mathrm{v}$ centrech $\mathrm{s}$ dostatkem zkušeností s touto léčbou a s kardiochirugickým zázemím. Magnetická rezonance je uznávanou metodou v dlouhodobém sledování pacientů s $\mathrm{CoA} / \mathrm{reCoA}$, a to především pro svou vysokou senzitivitu, absenci škodlivého záření a neinvazivní charakter.
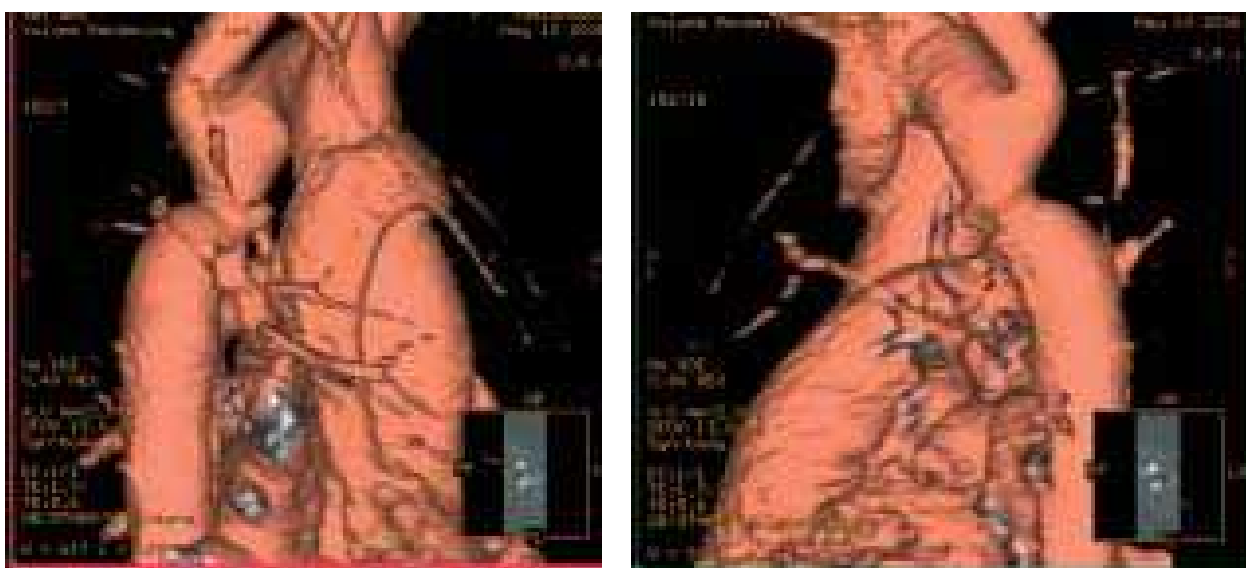

Obr. 2 a 3 3D rekonstrukce vyšetření v 3D-FFE sekvenci po aplikaci Gadolinia - zlepšení nálezu, rozšiřrení rekoarktace, nyní bez parametru odpovídající hemodynamické závažnosti; nově pseudodivertikl na ventrální stěně v místě rekoarktace

Asymptomatická pacientka ve věku 32 let po operaci CoA v dětství (anastomóza end-to-end), se dostavila do naší ambulance ke konzultaci před plánovanou graviditou. Byla zjištěna reCoA se systolickým gradientem mezi pravou horní a dolní končetinou $40 \mathrm{~mm}$ Hg. Pacientka byla odeslána na vyšetření magnetickou rezonancí, kde pro údajnou alergii na jód odmítla podání kontrastní látky. Vyšetřením byla prokázána významná přibližně $60 \%$ reCoA aorty za odstupem levé a. subclavia (obrázek 1). Aorta nad zúžením měřila $19 \mathrm{~mm}, \mathrm{v}$ nejužším místě $8 \mathrm{~mm}$ a za zúžením $22 \mathrm{~mm}$. Nemocnou jsme indikovali k provedení perkutánní balonkové angioplastiky. Invazivně stanovený výchozí tlakový gradient (pressure gradient - PG) byl $55 \mathrm{~mm}$ $\mathrm{Hg}$, po opakované dilataci balonkem $20 \times 40$ mm klesl PG na 20 mm Hg. $\mathrm{S}$ odstupem jednoho týdne byla provedena kontrolní magnetická rezonance, tentokrát již s aplikací Gadolinia, která potvrdila přiznivý nález po provedené angioplastice (obrázky 2 a 3). V nejužším místě měřila aorta $15 \mathrm{~mm}$, což odpovídalo přibližně $25 \%$ reziduální reCoA. Nově byl popsán drobný pseudodivertikl na ventrální stěně aorty $\mathrm{v}$ místě reCoA. Gradient mezi pravou horní a dolní končetinou zcela vymizel. V dlouhodobém sledování nemocných s CoA a reCoA patři magnetická rezonance ke standardnim vyšetřením především u pacientů, kteří podstoupili balonkovou angioplastiku pro možnost recidivy reCoA či rozvoje aneurysmatu jako komplikace provedeného výkonu.

\section{LITERATURA}

1. Mahadevan V, Mullen MJ. Endovascular management of aortic coarctation. Int $\mathrm{J}$ Cardiol 2004;97:75-8.

2. Carr JA. The results of catheter-based therapy compared with surgical repair of adult aortic coarctation. J Am Coll Cardiol 2006;47:1101-7.

3. Krueger JJ, Ewet P, Yilmaz S, et al. Magnetic resonance imaging-guided balloon angioplasty of coarctation of the aorta: a pilot study. Circulation 2006;113:1093-100

Marie Sedláková, Jiří Lisý, Josef Veselka

Kardiovaskulární centrum pro dospělé, Klinika zobrazovacích metod, Fakultní nemocnice Motol, Praha, Česká republika

Adresa: MUDr. Marie Sedláková, Kardiovaskulární centrum pro dospělé, FN Motol, V úvalu 84, 15018 Praha 5, Česká republika, e-mail: sedlak.marie@seznam.cz 